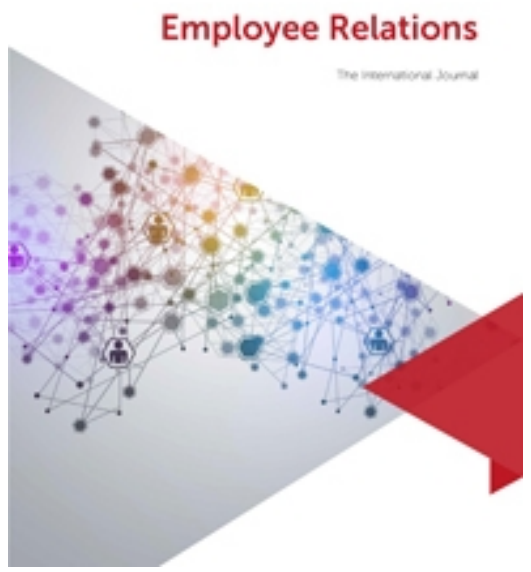

Workers' resistance in special economic zones in Poland

\begin{tabular}{|r|l|}
\hline Journal: & Employee Relations \\
\hline Manuscript ID & ER-08-2019-0310.R2 \\
\hline Manuscript Type: & Research Paper \\
\hline Keywords: & $\begin{array}{l}\text { Worker resistance, special economic zones, Foreign Direct Investment, } \\
\text { Poland, Trade Unions, sabotage }\end{array}$ \\
\hline \multicolumn{2}{|l}{} \\
\hline
\end{tabular}




\title{
Workers' resistance in special economic zones in Poland
}

\begin{abstract}
Purpose: This article compares workers' resistance in foreign direct investments in the automotive and electronics sectors in two special economic zones in the North-East and South-West of Poland. It aims to investigate why, despite the shared characteristics of the special economic zones, that there are different outcomes in terms of the balance of formal resistance through trade unions and informal resistance through sabotage.
\end{abstract}

Design/methodology/approach A spatial framework of analysis is posited to examine how global capital, national employment frameworks, and regional institutions play out in local labour markets and shape workers' sense of place and their capacity for workplace resistance. The research is based on interviews with trade union officials and non-union employees in 4 foreign investment firms in Poland.

Findings: The findings point to the importance of the type of production in influencing the structural power of organised labour and the social-agency workers influenced by their understanding of place.

Originality/value: Analysing workplace resistance and industrial relations from a spatial perspective.

Keywords: Worker resistance, special economic zones, Foreign Direct Investment, Poland, trade unions, sabotage

\section{Introduction}

In the post-1990 period of transformation Polish trade unions were deemed to be weak and marginalised (Gardawski et al., 1999). The deep restructuring of the economy with 
the closure or privatisation of State-Owned Enterprises, coupled with employment opening up in the service sector through an influx of foreign direct investment (FDI), reduced union density from 28 per cent in 1991 to 11 per cent in 2014 . However, by the mid-2000s this pessimistic analysis had been tempered by developments that suggested a modest revival in trade union activity in terms of recruitment, organisation and new tactics. High profile protests by nurses in 2007 and the formation of new union branches in greenfield manufacturing foreign investments and the service sector provided evidence for cautious optimism (Mrozowicki et al., 2010; Hardy and Kozek, 2011; Mrozowicki and Maciejewska, 2013).

Seminal articles by a new generation of Polish industrial relations scholars have documented the historical background, institutional evolution and obstacles to organised labour in Poland (Czarzasty et al, 2014; Czarzasty and Mrozowicki, 2018). However, contributions to the industrial relations literature in Poland have been lacking in two respects. First, it has been geographically blind in terms of the absence of a spatial perspective as integral to analysing the capacity of workers to organise and resist. Second, research to date on Polish labour organisations has been predominately oriented on the formal organisation of trade unions and collective action in the form of protests and strikes rather than encompassing wider understandings of workers' resistance. There have been notable exceptions to this approach, with contributions to the literature on workers resistance: in Poland's special economic zones (Maciejewska, 2012; 2016); to precarious employment (Karolak and Mrozowicki, 2017); and on Polish returning migrants (Karolak, 2016). This article aims to contribute to this literature by bringing together an analysis of workers resistance, broadly conceived, with a geographical perspective and to seek linkages between them. 
The empirical focus of the article is an examination of workers' resistance in FDI in the automotive sector in the Wałbrzych Special Economic Zone (SEZ) (South-West Poland) and FDI in the electronics sector in the Pomeranian SEZ (North-East Poland). Both of these SEZs are located in regions that are economically disadvantaged and peripheral to the main sites of production in the country. The article poses the question as to why different configurations of formal and informal workers' resistance are manifest in these foreign investment manufacturing workplaces in the case study SEZs. In order to address this research question a broader perspective of workers' resistance is taken to include those actions that lie outside the boundaries of formal industrial relations by redefining workers' collective action to embrace wider manifestations of employee discontent. Conceptually the article draws on and brings together insights from the literature on labour geography and workers resistance to posit a spatial perspective that enables an exploration of how specific forms of worker resistance are produced in the case study SEZs.

The structure of the paper is as follows. It begins by positing a spatial conceptual framework that suggests that trade union organisation and the balance of formal and informal resistance is the outcome of intertwining social processes at different scales that influence workers' sense of place. The methodology and data collection are then discussed. The article goes on to outline the spatial process in which the case study firms are set by focusing, first on global firms and local space and second on the national context of industrial relations. The data is presented by examining workers' resistance and their sense of place in the case study firms in the two SEZs. This is followed by a discussion that draws out themes and conceptual insights from the data.

\section{A spatial perspective of industrial relations}


This framework builds on assertions that employment relations are necessarily sociospatial relations (Ellem, 2016). Work is typically understood as a practice undertaken by individuals or groups in physically proximate space, however, this monoscalar assumption needs to be replaced by understanding work as constituted through many scales and their associated linkages. Following Rainnie et al., (2010) the analysis is underpinned by the assumption that 'a geographically informed approach to understanding the workplace is necessary...what occurs on the shop floor is shaped by the spatial context in which these occurs (298-299)'.

Capital can be thought of as trying to disorganise labour by segmenting the labour market by place (Hudson, 2001). However, while capital creates different sites of accumulation through investment and disinvestment (Harvey, 1982) the geographies of labour are not wholly determined by capital, rather they are formed at an intersection 'where flows of capital accumulation collide with structures of communities' (Peck, 1996:16) and organised workers in particular.

The concept of mobility is salient for understanding spatiality as capital seeks a 'spatial fix' by looking for new areas of investment to lower costs as part of competitive accumulation (Harvey, 1982). However, labour migration also shapes the unfolding of geography of the labour market in a locality by seeking alternative sites of employment, within and outside the nation state, where wages and working conditions might be better. This in turn is shaped by wider regulatory national or supranational spaces in which the export or import of labour is framed.

The approach to industrial relations taken in this article addresses the critique of Herod et al., (2007). First, the analytical framework goes beyond viewing actors as 'contained' 
in particular units, but rather starts from the assumption that they are materially and institutionally embedded at many spatial levels. Second, rather than viewing geography as a 'complicating' contextual factor the approach identifies different interlinked spatial levels that interact and unfold in distinct ways. Third, spaces of capital and places where workers live and work are not a static given but are materially and politically constructed and constantly in a process of mutual (re)constitution. Every local labour market is therefore a conjunctural structure with a 'dynamic interplay among generative forces' (Peck, 1996), shaping and shaped by the possibilities of workplace resistance. Further, by extending the notion of micro and macro to include supra- and sub- national levels of space, the analysis contributes to the debate identified by Pulignano and Doerflinger (2018) about the relationship between national regulatory structures and the dynamics of the workplace.

Scales are socially constructed, porous and there is no simple hierarchy from which social processes can be read off and neither can different spatial levels be understood as containing particular social processes (Ward, 2007; Peck, 1996). However, for the purposes of exploring and analysing the data the framework of analysis identifies four broad spatial levels and the social processes that are associated with them in order to facilitate a discussion about the complex ways in which they are interrelated.

\section{Global, national and regional spatialities}

At a global level FDI is part of the value chains of large transnational companies (TNCs) and therefore spatially embedded production processes are locked into transnational flows. The place of a subsidiary in the global value chain of a firm will determine the scale and nature of production as well as its mobility. Central to the labour process and the 
ability of the firm to relocate is the extent of sunk costs in a project, the requisite skills for production, the stability of demand for the final product and the degree of competition for an investment in terms of whether the attributes of a location can be replicated elsewhere. Pulignano and Keune (2015) emphasise the way in which product market characteristics affect local autonomy to determine human resource policies. The type of skills required, and costs invested in training workers may frame industrial relations within the firm. The higher the level of skills and length of training required the more concerned the firm is likely to be to retain workers through welfare benefits and negotiating adequate industrial relations structures to manage grievances. Further, the extent of embeddedness in local networks of suppliers and institutions may affect the mobility of firms (Hardy et al., 2005).

The institutional regulatory structures of the national context will shape workplace organisation (Pulignano and Doerflinger, 2018). This includes the shaping of the geography of production by the state through incentives to locate in particular areas and the degree to which it has capacity for capturing foreign investment through it dedicated national and local inward investment organisations. Further, the legislative framework of employment will shape the rights and entitlements of workers in terms of contracts, workplace welfare and health and safety. The material incentives for labour mobility will be underpinned by uneven development within and between countries and legislation that pertains to the export and import of labour.

The specificities of individual trade unions within the national context will influence their strategies, capacity and success with regard to: recruitment, organising and mobilising discontent into industrial action. These unique organisational identities will be the 
outcome of historical legacies, political affiliations and how this influences their embeddedness in international labour movements.

Exogenous global processes and endogenous national institutions are brought together by the analytical framework of Varieties of Capitalism (Hall and Soskice, 2001) that has been extended and sensitised to enable a taxonomy of Central and Eastern economies. There has been much debate about the most appropriate model (Rapacki et al., 2020), but most salient for this analysis is the addition of a third category dubbed 'Dependent Market Economies' (DME) advanced by Nölke et Vliegenthart (2009). This DME model emphasises the comparative advantage of these economies as lying in the assembly and production of relatively complex and durable consumer goods. Poland (and other economies) draw on institutional complementarities between skilled, and relatively cheap labour, the transfer of technological innovations within transnational enterprises, and the provision of capital through FDI. FDI and national institutions are codeterminous in that the arrival of FDI will be underpinned by expectations of a minimal institutional framework (property rights and rule of law for example) and FDI in turn will influence institutional development (further legal frameworks and workplace practices).

The interaction of structural and institutional dimensions of global and national spatialities will be reflected in regional and local labour markets. Myant and Drahokoupil (2012) propose a more nuanced taxonomy for understanding the international integration of post-communist economies that is highly relevant for understanding regional impacts of FDI. This includes distinguishing between: exportoriented FDI in complex sectors; export-oriented sectors without FDI; simple 
manufacturing sub-contracting to MNCs: commodity exports; dependence on remittances and aid; and dependence on financialised growth.

However, localities and regions are not simply empty vessels in which these factors play out as these are active sites of policy making, communities and groups of workers. Gonzalez-Menendez et al., (2018) highlight the importance of the region in institutional adaptation to the requirements of international capital. This will be dependent on the degree of autonomy afforded to regions, within a national framework, to construct a regional alliances of actors and the extent to which they subscribe to market-centred-, state-coordinated or associational governance modes (Almond et al., 2017). In relation to the region, historical legacies of workers organisations may encourage or inhibit the establishment and growth of labour organisations.

\section{Work 'place' dynamics}

Social-actor based explanations (Drahokoupil et al., 2015) contribute to a nonteleological approach in understanding how these spatialities unfold in terms of workers' sense of place. First, this sense of place might be dominated by an understanding of where the workplace sits in the global value chain of the firm. Further, the role and participation of workers in the international networks of the firm and trade unions federations within them may provide knowledge, support and confidence pertinent to organising within the site of production. Second, choice of membership and activism in a specific trade union in the context of national traditions and politics will link workers to a strong sense of national space, albeit in differentiated ways. Third, geography and perceptions about region within national space could support or undermine workers' confidence to resist depending on a locality's inclusion/exclusion from economic benefits and institutional structures. Therefore it is argued that these 
intertwined spatialities will shape the workers' sense of place and influence the form and type of workers' resistance.

Worker resistance itself may take a variety of forms, and therefore attempting to taxonomise the concept poses some difficulties (Richards, 2008). For the purposes of this article, the main axis of division runs between the formal and organised resistance of trade unions and the informal and unorganised resistance of workers outside of formal labour organisations. Organised and active collective workers' resistance is manifest in corporate campaigns, industrial action, workplace occupations, blockades and trade unionism in general. Taking more subtle and indirect shapes, disorganised, informal and individual forms of resistance are challenging to define. Action may include sabotage, theft and pilfering (Brown, 1977; Ditton, 1977) and 'fiddles' (Webb and Palmer, 1998). More subtle forms of resistance may include sarcasm, joking, use of nicknames, gossiping and mocking that can either be present in workplace discourses or increasingly electronic forums (Taylor and Bain, 2003; Schoneboom, 2011). In this respect the boundaries of the 'contested terrain' (Edwards, 1979) of workplace relations are expanded. For the purposes of this article workplace 'sabotage' is understood as: 'any behaviour by a payroll employee which is intended to inflict a production or profit loss for the targeted organisation.' (Giacalone and Rosenfeld, 1987: 367)

The relationship between interrelated spatial scales and how this is manifest in the capacity of workers for formal resistance through trade unions or collective and individual informal resistance is complex. It might be predicted that mobile capital employing a low skilled labour process in the institutional context of permissive employment legislation and weak national trade unions, with regional structures that 
lack autonomy, taken together lead to challenging conditions for formal workplace organisation. Conversely capital with a high level of sunk costs requiring skilled workers in a national context of strong employment protection, well-established unions and autonomous regions is likely to provide much more propitious conditions for formal workplace organisation. However, these are hypothetical scenarios and workers' sense of place is shaped by the intertwining of different spatial levels that unfold in workplaces in distinct ways.

\section{Methodology and data collection}

The manufacturing subsidiaries that form the case studies comprise one electronics firm (Kessho) and one of its lead suppliers (Matado) in the Pomeranian SEZ in North-East Poland and two subsidiaries from same parent company, Izumo I and Izumo II, in the automotive sector in the Wałbrzych SEZ in South-West Poland. The fieldwork was undertaken in the Pomeranian SEZ between 2011 and 2012 and in the Wałbrzych SEZ in the first half of 2017. The four-year hiatus between the two sets of interviews was as a result of securing a second round of funding and the long process of gaining access. Comparability is enabled by similar economic and institutional conditions pertaining in both periods. The distribution of interviews is shown in Table 1.

\section{Table 1 here}

Semi-structured in-depth interviews were conducted with trade union representatives and non-union employees. Initial contact with trade unions was made through the regional offices of Solidarność in Toruń (Pomeranian SEZ) and Wrocław (Wałbrzych SEZ). This enabled interviews with the Branch Presidents but also with non-unionized 
workers. Each interview lasted between thirty and sixty minutes and were conducted in Polish (by one of the authors) transcribed and translated into English.

\section{The spatial social-processes in two SEZs}

This section explores spatial social-processes that affect the workplaces in the two case study SEZs. First, it focuses on the place of the case study firms in global production networks, the characteristics of the regions and the employment policies of the firms. The second part of the section focuses on the national context of employment and industrial relations frameworks.

\section{Global firms, local space}

The characteristics of the labour market in both SEZs prior to investment were very similar with significantly high unemployment, wages below the national average and low union density. To understand the nature of spatiality a more fine grained approach is needed to distinguish between the relatively low unemployment in the towns compared to their rural hinterland. This is shown in Table 2.

\section{Table 2 here}

The workforce in the automotive firms in the Wałbrzych SEZ tended to be drawn from the town and a small radius around it, while workers from electronics firms in the Pomeranian SEZ were 'bused in' from small villages at long distances typically ranging from 40 to 60 kilometres. In the Wałbrzych SEZ unions were decimated after the collapse of the mining industry and the Pomeranian SEZ was located in a rural area previously dominated by agricultural employment and without a tradition of labour organisation. The case study firms were Japanese and their location decisions followed their preference for investing in peripheral regions designated as SEZs in other parts of 
Europe. Kessho in the Pomeranian SEZ started production in 2007 assembling LCD modules for itself and two other global brands. Sales were predominately focused on the European market. Following its cluster investment pattern, Kessho attracted twelve other Japanese electronics, chemical and logistics companies that became part of the socalled 'Crystal Park. Between 2007 and 2012 it constituted the biggest Japanese electronics 'cluster' in Poland.

Izumo I and Izumo II are located in the Wałbrzych SEZ and started their operation in 2000; by 2008 the site had expanded threefold with the initial workforce of three hundred workers growing to 2,000. The firms in the Wałbrzych SEZ manufactured gearboxes and engines for the Izumo assembly plant located in Czech Republic.

In Kessho the managerial class and highly skilled engineers were recruited from all over the country, as the Pomerian region was deficient in highly-specialised engineers. The employment of shop floor workers was characterised by low job security and high turnover with 50 per cent workers employed by three international employment agencies. These temporary workers were employed on one-month contracts, which could be extended every month. To avoid permanent employment, Kessho either laid workers off after the eighteen-month period had expired, or re-employed them on a new contract. From 2011 onwards there were regular rounds of redundancies in Kessho, Matado and the other component manufacturers; employment in Kessho decreased from over 2,000 in 2010 to 1,000 in 2011.

Izumo was characterised by relatively stable employment with the majority of workers employed by the company for more than ten years; 80 per cent of workers were above thirty-five years old. A small number of workers were employed on temporary 
contracts, but they were retained even when demand temporarily decreased. The work was intensive and driven by rolling targets for decreasing costs and improving quality.

\section{The national framework of industrial relations}

While the previous section was a capital dominated account of spatiality, this section turns to outlining the national context of industrial relations in Poland. In the post-1990 period of transformation Polish trade unions were significantly weakened as the rapid restructuring of State Owned Enterprises and closure of State Owned Enterprises weakened their membership base (Rainnie and Hardy, 1995; Kozek et al., 1995; Gardawski et al., 1999). Politically the inactivity of OPZZ (Ogólnopolskie Porozumienie Związków Zawodowych [All-Poland Alliance of Trade Unions]), the official union under the communist regime, and compliance of Solidarność with market-led reforms led to little opposition to redundancies and lower wages (Ost and Weinstein, 1999; Ost, 2005). Extreme labour market flexibility in Poland has further diminished the influence of trade unions. Union density substantially dropped from 65 per cent in 1980 to 28 per cent in 1991 and 11 per cent in 2015 (Mrozowicki and Maciejewska, 2017).

The historical origins of Solidarność and OPZZ in opposing or complying with the communist regime resulted in acute hostility between them after 1990 and support for or opposition to governments based on political affiliation. However, these deep political divisions in the labour movement started to diminish from 2009 with the formation of FZZ of (Forum Zwiq̨zków Zawodowych [Trade Unions Forum]) and with emerging ad hoc examples of cooperation between all three trade union federations over specific issues at national, regional and local level (Hardy, 2009).

Following Czarzasty et al., (2014) it is argued that the specificity of individual trade union federations in relation to their degree of centralisation and embeddedness in 
international trade union structures is critical to understanding the potential for workplace organisation. For example, Solidarność moved to union organising relatively easily in the context of the extensive financial and practical support from the American AFL-CIO (pre- and post- 1990) and German, and British trade unions (post-1990). This degree of centralisation of the organisation enabled the transfer of resources between different campaigns and functions. OPZZ and FZZ, however, are federated organisations and decentralised with a significant degree of autonomy for their affiliated organisations. These federations are therefore much more reliant on grassroots mobilisation and the activism of workplace level leaders. Further, the relative success of trade unions based on narrow occupational interests should be noted, for example KADRA representing supervisory workers (Ibid).

Despite trade union density being historically low, there has been an increase in workers' confidence. First, the exodus of workers in 2004 after Polish access to the European Union and subsequent fall in employment led to tighter labour markets and more structural power for workers (Meardi, 2007). Second, union revitalisation is evident (Mrozowicki et al., 2009; Hardy and Kozek, 2011; Kubisa 2014) with trade unions established in greenfield foreign investments in Poland's SEZs (Mrozowicki and Maciejewska, 2013, Maciejewska 2016, Amazon Workers and Supporters, 2018).

\section{Workplace relations in two Special Economic Zones: Findings}

This section will report the formation and activities of trade unions and informal resistance in the case study firms: automotive manufacturing in Izumo I and Izumo II in the Wałbrzych SEZ and the Kessho (assembly) and Matado (supplier) in electronics firms in the Pomeranian SEZ. 


\section{Wałbrzych Special Economic Zone}

At Izumo I and Izumo II Solidarność was the first union branch to be established in 2005, followed by the establishment of OPZZ and the KADRA trade union in Izumo I in 2008 (affiliated to FZZ). Trade union density is summarised in Table 3.

\section{Table 3 here}

While ninety per cent of the membership of Solidarność were shop floor workers, OPZZ and KADRA attracted team leaders and highly skilled engineers. The formation of KADRA was motivated by disagreements with Izumo's management about their productivity and quality policies, but by them not wanting to be represented by Solidarność. Subsequently, both OPZZ and KADRA attracted shop floor and administration workers, and even some managers, into membership. One of the OPZZ representatives at Izumo I explained her reasons for joining and becoming active in the trade union:

I joined a trade union because I couldn't stand the humiliation. The management says that we should be more appreciative, ultimately we have stable jobs, the company pays for social security and benefits adding that other companies do not offer these 'perks'. To diminish our work and efforts managers repeat that we are not assembling cars, just components. This supposedly means that our work is worthless. Workers can be moved from one department to another several times per year without any reason.

In the early stages of establishing the three trade unions in the factories, the lack of cooperation between them reflected historical antipathy at a national level. When OPZZ 
and KADRA, jointly organised a strike referendum in 2014 the initiative was not supported by Solidarność, which undermined its success. One OPZZ member described the circumstances:

\author{
This referendum was about pay increases and bonuses...There was an \\ atmosphere of bullying. We didn't win, but we nearly reached 50 per cent \\ support for the strike action. Still, I regard this action as a success, we \\ showed we can mobilise our workers. I think we failed because trade \\ union organisations couldn't cooperate.
}

Trade union activists understood that this division plays into management hands. An OPZZ trade union member explained:

\begin{abstract}
They [the management] played us couple of times: Solidarność signed a separate agreement, sometimes we did. The management knows, that this is a short-term policy. When they reach an agreement with only one union, it may backfire in the next year (as we have five unions organisation across two companies).
\end{abstract}

From 2015 all three trade unions in Izumo I and Izumo II began to cooperate, both within and between the two sites. A turning point was the production of a joint recruitment leaflet produced by Solidarność, OPZZ and KADRA, which argued that the intensification of work should not be at the expense of the working conditions of workers. Since late 2016 all three unions have taken part in joint pay negotiations with management. However, the trade union representatives in Izumo I and Izumo II did not consider their 
activism as spectacular achievement, rather a daily grind, and a battle with management for basic rights. As one Solidarność representative explained:

\begin{abstract}
Our role is to make the employer sit at the table, discuss and implement the changes which are just to conform to the law. For instance thanks to our intervention the firms' Social Fund works in line Polish law. We have managed to establish a Social Labour Inspectorate - there are very few companies in the country where unions actually introduced this Inspectorate.
\end{abstract}

The perception of place by Izumo workers was twofold; they understood their comparative position both in the context of wider networks and sites of the firm and their competitive position in the locality. The quote from one worker compares the intensity of work in Izumo with a factory in Britain and attributes this to bargaining power;
I have heard from my colleagues who went there [to England] for training, that actually workers are quite relaxed on the shop floor, while here we are working our $\mathrm{a}^{* * *}$ off, as robots do. The speed of work is much higher here... There is more employment in the UK. There is a different Izumo in Poland and there is a different one in the UK...People have more bargaining power over there, they are able to exercise their rights to a greater extent, they vote with their feet. Here, we are not able to do that.

The workers interviewed pointed to other aspects of their working conditions in Poland as being inferior, for example facilities for breaks. They were particularly concerned 
about low wages which compelled them to work overtime to make a living wage. This is reflected in the following comments by one interviewee;

Here we are closer to 'Western prices', and still we earn 'Eastern' wages.

Both in Japan and the UK, workers do not do overtime on Saturdays.

This is the time reserved for families, for themselves. Here on the other hand, workers are doing overtime, whenever possible to make the ends meet. That's the main difference.

However, one interviewee argued that their competitive position in the region might improve because of the opening of a new Mercedes factory 25 kilometres away:

We are aware that the presence of this factory will work in our favour. Additionally, if they offer higher pay, may people would decide to apply. Izumo will struggle with labour shortage. Here, people have at least ten years' experience in the industry, they work with similar machines. We understand, that we would be very competitive.

\section{Pomeranian Special Economic Zone}

The workers interviewed in the firms in the Pomeranian SEZ demonstrated an acute understanding of place in terms of the peripherality of and lack of opportunities in the region. The following quote from a Solidarność representative reflects their dependence on the incoming new investments;

I can't imagine the region without these factories. The town where I live, literally revived because of the Japanese investors. In my block of flats, the majority of people are employed in Crystal Park. Before, they 
[Japanese] came there was no work at all. The sugar-refinery, the biggest employer in town, employs workers for only three months during the sugar beet harvest, that's it. Crystal Park factories are our saviours... I know they [Japanese companies] only pay national minimum, but this is still stable employment. We had no factories here.

Interviewees consistently expressed a fear of being unemployed and referred to the lack of opportunities in the region. The following quotes from an interviewee is typical;

The economy is struggling and we are struggling. You know how it is. Money is money. I have to work here, I have no alternative. I have kids. I work here because I have to make a living, not because I like it. Of course, the work is very hard and stressful. But where else will I go? There is nothing in my town.

The lack of alternative employment opportunities left people feeling impotent and fearful of losing their livelihoods. Nevertheless Solidarność was successful in establishing branches in two of the factories in the Crystal Park cluster. The first was established in Kessho (the lead firm) in 2007 just after the investment had arrived. However, the second branch of Solidarność was only established in Matado (a supplier) five years later in response to deteriorating economic performance of the company and consequent redundancies. None of the other firms in the electronics cluster established trade union branches. Table 4 summarises the trade union presence in Kessho and Matado.

\section{Table 4 here}


The representative of Solidarność in Matado describes the difficulties in establishing a union branch in the face of hostile management and workers who were afraid of jeopardising their jobs. Beyond a hostile manager there were difficulties in persuading people to join the union. The Solidarność representative in Matado explained:

We had to take the risk. Our jobs were at stake. No one wants to make such a decision. Only very few of us had enough courage to do that. Establishing a union meant we were prepared for the possibility of losing our jobs. I guess we were so desperate that we didn't care so much in the end.

Further, the geographically dispersed nature of the workforce posed problems for building the union. The representative of Solidarność continued;

Organising the union is very difficult. Practically, the only time we can talk and gather them is during the lunch break, still you can't reach everyone. As most of the workers commute by organised buses, they are gone after the shift finishes, so we can't talk to them after work.

In the Pomeranian SEZ Solidarność was the only trade union operating. It had relatively high profile in the Torun region, in which the SEZ was located, and was well-organised and active, especially in the manufacturing sector. Therefore, Solidarność became the union of choice for Crystal Park employees rather than OPZZ. The trade unions in Crystal Park, however, did not manage to protect workers from massive redundancies in 2012 and 2013. In 2011, to avoid paying redundancy packages, Matado management laid-off just under thirty workers, on a weekly basis. 
The absence of trade unions in most of the firms in the Pomeranian SEZ and the low union density in the two firms where branches had been established did not mean that workers were passive with regard to workplace discipline, job intensification and working conditions. The findings revealed extensive examples of individual or collective action independent of trade unions as workers contested both workplace organisation and personal mistreatment on the shop floor through sabotage, humour and walkouts.

Interviewees cited extensive examples of sabotage. One of the engineers on a night shift at Kessho recalled:

In the middle of my night shift I was called to the production hall. The night shift leader reported that the transmission belt had broken. Production stopped and workers stood by the line or sat on the floor. They knew they had a couple of hours before it could be fixed. When I checked the damage I knew immediately that it was not accidental. Someone deliberately did it! I have seen many similar kinds of damage and can tell a genuine one from the one that was 'helped'...There was one night when they really 'took the mickey'. The belt was cut in several places. I managed to fix one bit and another one was going. It really annoyed me then. I had to spend extra hours in the shop floor.

An engineer at Matado explained how sabotage was a regular occurrence;

There were these safety buttons that stopped the assembly line, EMO [Emergency Machine Off] ...but people were randomly using it to stop the machine for non-emergency reasons. Especially during the night shifts. When it was too busy, or for a joke, or because they wanted a break. 
The previous two accounts were infused with humour. In another example of humour one interviewee, when asked about his attitude to workplace discipline and the obligation to report the cause of damage to the management, referred to a popular communist era TV series in 1986;

When at work, my name is Marian Koniuszko! [laugh; (Polish: 'W pracy nazywam się Marian Koniuszko'].

The Koniuszko character is a perfect archetype of opportunism and carelessness. He is a bit spoilt and lazy and only does the bare minimum required; yet despite these flaws he always manages to land on his feet.

Apart from sabotage that was intended to slow the pace of work and gain workers some free time in Matado and Kessho, workers admitted knowing about practices of deliberate carelessness when handling the finished products or unloading the delivery. They cited warehouse workers tossing boxes with finished parts and transporting pallets without due care. Another form of 'taking revenge' was the practice of screen scratching. One of the workers in Matado confessed:

The bonus we deserved was not paid and some people got angry and disappointed. And to get revenge they would scratch the screens or frames sometimes before packing tellies in the box, so the company would get a return. They are not going to pocket our money. If we are not getting it, they are not getting it either.

Many of the workers interviewed expressed disapproval of such practices; yet at the same time there was an understanding of the behaviour of the 'rebels'. Some blamed bad working 
conditions and mistreatment, others cited the boredom of repetitive work and suggested that 'doing this for eight hours would turn everyone insane'.

\section{Discussion}

Since 1990 successive Polish governments have structured national and regional space in a way that is conducive to the arrival of foreign investment (Hardy et al., 2005). Institutionally permissive employment legislation that enabled short term contracts and encouraged the entry of employment agencies as conduits of precarious labour made Poland attractive - even in relation to other EU post-communist countries - as a site for investment by TNCs. Enclaves designed for foreign capital took the institutional form of Special Economic Zones (Maciejewska, 2012). These were economically and politically constructed spaces in areas of high unemployment designed to attract capital on the basis of low labour costs (even in the Polish context) and subsidies for infrastructure and tax breaks. The absence of labour organisations as a result of the decimation of mining in the Wałbrzych SEZ and agricultural based Pomeranian SEZ made them attractive spaces for Japanese capital, which had shown a similar preference for such regions elsewhere. The neoliberal orientation of successive Polish governments, their reliance on FDI and lack of autonomy of regional governments meant there was an institutional vacuum. Local institutions were left as cheerleaders of foreign capital rather than active partners.

An initial reading of these conditions, consistent the categorisation of Poland as a DME, might suggest the disempowerment of labour and very challenging conditions for organising and resisting. However, the data suggest different outcomes in the two case 
study SEZs. In the Pomeranian SEZ the formation of trade unions and recruitment had limited success and workers resorted to individual and collective informal resistance. Workers in the Wałbrzych SEZ were successful in establishing unions, recruitment (over 50 per cent of members) and establishing a system of workplace industrial relations. Therefore a more nuanced analysis is required to understand and explain these differences. It is posited that this rests on two critical factors. The first explanation relates to the structural power inherent in the type of production and the second focuses on the social-agency of workers in relation to their understanding of place.

First, the section of the value chain of global capital captured by the region is salient and resonates with Myant and Drahokoupil's (2012) taxonomy of the form of integration with the global economy through FDI. In the case of the automotive firms in the Wałbrzych SEZ production was part of a European network of automobile production with stable demand. In addition, they had been successful in a locational tournament for a new round of investment in manufacturing engines for electric cars. The firm's strategy of continuous improvement to cut costs and improve quality was reliant on skilled and efficient workers. Securing their compliance resulted in permanent employment contracts, and under pressure from trade unions investing in industrial relations structures to channel the grievances of the workers. In contrast the electronic firms in Pomeranian SEZ produced goods with fluctuating demand that were supplied directly to the market. Production was comparatively mobile and therefore when the financial incentives of the SEZ were exhausted it was easy to shut down or move production.

Second, the social agency of workers in terms of their understanding of place influenced their confidence and capacity for organising and the potential for resistance. In 
Wałbrzych workers had an understanding of local/regional place in the context of European and global space as a result of being trained in other countries; knowledge gleaned was diffused throughout the workforce. This gave workers a sharper understanding of their place in wider value chains and greater sensitivity to their own exploitation. This served as a driver to campaign for increased pay and better conditions. It cannot be ruled out that the local working-class traditions, the Solidarność heritage and the ethos of collectivism in the former mining area of Wałbrzych haven't played any part in the unionisation and deeper understanding of the globalised industry. However, workers in Wałbrzych did not feel a strong connection with a past mining tradition of the region formerly strongly embodied by Solidarność, surprising as the Japanese investment came ten years (early 2000s) after its collapse. A new generation of workers were employed in the car factory and in this sense, workers consciousness grew out of this new lived-experience of intense work and low pay that led to feelings of exploitation - rather than any passed sense of belonging with the miners' tradition.

Workers in the Pomeranian SEZ had a more parochial understanding of place in relation to the peripherality of and lack of opportunities in the region. The more dispersed nature of regional space as workers were scattered in small and distant villages also gravitated against a more collective sense of place. The pervasiveness of fear of unemployment led to trade unions being established in only two firms in the cluster, both with low density (30 per cent and 10 per cent). However, this did not translate into compliance with or acceptance of poor working conditions, and although the formal organisation of labour was at a low level there were frequent and persistent references to sabotage in the accounts of the workers. 
Therefore, while the Pomeranian workers lacked these collective traditions and felt more isolated from the global chain (closed cluster of factories in one location; short lived investment and short-term operation; most of the components for the finished product were made locally in the neighbouring factories; lack of effective engagement with European Work Councils), Wałbrzych Special Economic Zone produced, as workers describe it, 'the heart of a car' (engines and gear boxes) and workers saw their place in the global automotive industry in a similar way.

The specificities of national trade unions were influential in workplace organisation. Solidarnośćs national framework of organisation was able to support and contribute to the limited success of establishing branches in the Pomeranian SEZ, while OPZZ and FZZ had no presence. In Wałbrzych, although Solidarność was the first trade union established, it was not seen as representing workers above basic grades and a bottomup initiative led to the formation of OPZZ and FZZ branches. This is untypical for other Japanese automotive corporations in the region, which are rather reluctant in recognizing trade unions and where the union density is relatively low (Drahokoupil et al., 2015). The most interesting feature of the trade union organisation in Izumo was their ability to overcome fractious and fractured relationships at the national level of Polish unions to cooperate locally in negotiating with management. This underlines the importance of social-agency and challenges assumptions that workplace organisation can automatically be read off national institutions (Gardawski et al., 1999; Nölke and Vliegenthart , 2009). 


\section{Conclusion}

A weakness of the research is that it only compares workplaces with two different forms of global economic integration through FDI in two regions. Further case studies in different regions or comparisons within a region might enrich or challenge the findings. However, the strength of analysing workplace resistance and industrial relations from a spatial perspective avoids both structurally and institutionally deterministic accounts that can be inherent in VoC approaches. This study demonstrated that spatiality is critical in explaining industrial relations and workplace organisation in the two case study special economic zones in Poland. In other words, the interaction of different spatial levels enables an understanding of the microdynamics of workplace resistance in relation to formal and informal responses. Identifying the way in which social processes at global, national and regional level are intertwined and influence workers' understanding of place enables an understanding of the specificity of workplaces and the resistance of workers within them. Extending the boundaries of resistance beyond the formal organisation of trade unions underlines the social-agency of workers contesting poor employment conditions - even under the most difficult conditions. In terms of practical implication, this article can be used by the trade unions in Poland and elsewhere to demonstrate that workers are not passive, they effectively used their knowledge about the organization to build the trade union membership and fight for better working conditions. As this research indicated, trade unions' approach to organising local structures should also be recognizing the importance of the dynamic geography of trade unionism with its historical and institutional implications. 


\section{References}

Almond, P., M.C. Gonzalez, J. Lavelle and G. Murray (2017), 'The local in the global: regions, employment systems and multinationals, Industrial Relations Journal, Vol. 48 No. 2, pp. 115-132.

Amazon Workers and Supporters (2018), 'Stop Treating Us Like Dogs! Workers Organizing Resistance at Amazon in Poland' in J. Alimahomed-Wilson, I.Ness Choke Points. Logistics Workers Disrupting the Global Supply Chain. Pluto Press, London, pp. 96109.

Brown, G. (1977), Sabotage. A study in Industrial Conflict. Spokesman Books, Nottingham.

Czarzasty, J. and Mrozowicki, A. (2018), 'Historical relations: historical background, institutional evolution and research trends, employee relations, Vol. 40 No. 4, pp. 674691.

Czarzasty, J., Gajewski, K. and Mrozowicki, A. (2014), 'Institutions and strategies: trends and obstacles to recruiting workers into trade unions Poland', British Journal of Industrial, Vol. 52 No. 1, pp. 123-135.

Ditton, J. (1977), Part-Time Crime: An Ethnography of Fiddling and Pilferage. Macmillan, London. 
Drahokoupil, J., Myant, M. and Domonkos, S. (2015), 'The politics of flexibility:

Employment practices in automotive multinationals in Central and Eastern Europe', European Journal of Industrial Relations, Vol. 21 No. 3, pp. 223-240.

Edwards, R. (1979), Contested Terrain: The Transformation of the Workplace in the Twentieth Century. Hainemann, London

Ellem, B. (2016), 'Geographies of the labour process: automation and the spatiality of mining', Work, Employment and Society, Vol. 30 No. 6, pp. 932-948.

Gardawski, J., Gąciarz, B., Mokrzyszewski, A. and Pańków, W. (1999), Rozpad Bastionu? Związki Zawadowe w Gospardarce Przywatyzowanej [The Fall of a Bastion? Trade Unions in a Privatised Economy]. Instytut Spraw Publicznych, Warszawa Giacalone, R. A. and Rosenfeld, P. (1987), 'Reasons for employee sabotage in the workplace'. Journal of Business and Psychology, Vol. 1 No. 4, pp. 367-378.

Gonzalez Menendez, M.C., D.L. Balbona, G. Pruneda and P. Almond (2018), 'Embedding multinational firms in regional business systems: neoliberal and social-democratic models in Spain, Industrial Relations Journal, Vol. 49 No. 1, pp. 59-68.

Hall, P. and Soskice, D. (2001), Varieties of Capitalism: The Institutional Foundations of Comparative Advantage Oxford University Press, Oxford.

Hardy J. and Kozek W. (2011), 'Changing workplace relations in foreign investment firms in Poland'. Employee Relations, Vol. 33 No. 4, pp. 375-94.

Hardy, J., Currie, F., and Ye, Z. (2005), Cultural and Political Embeddedness, Foreign Investment and Locality in Transforming Economies: The Case of ABB in Poland and China. Competition \& Change, Vol. 9 No. 3, pp. 277-297. 
Harvey, D. (1982), The Limits to Capital. Blackwell, Oxford

Herod, A., A. Rainnie, S. McGrath-Champ (2007), 'Working space: why incorporate the geographical is central to theorizing work and employment practices, Work, Employment and Society, Vol. 21 No. 2, pp. 247-264.

Hudson, R (2001), Producing Places. The Guilford Press, London

Karolak, M., (2016), "From Potential to Actual Social Remittances? Exploring How Polish Return Migrants Cope with Difficult Employment Conditions". Central and Eastern European Migration Review, Vol 5 No. 2, pp. 21-39.

Karolak, M., Mrozowicki A. (2018), „Between Normalisation and Resistance. Life Strategies of Young Precarious Workers". Warsaw Forum of Economic Sociology, Vol. 1 No. 15 , pp. 7-32.

Kozek, W., Federowicz, M., and Morawski, W. (1995), 'Poland' in J. Thirkel, J, R. Scase, and S. Vickerstaff (eds), Labour Relations and Political Change in Eastern Europe. UCL Press, London, pp. 109-135.

Kubisa, J. (2014), Bunt białych czepków. Analiza działalności zwiq̨zkowej pielęgniarek i położnych [The rebellion of nursing caps. The analysis of trade union of nurses and midwives]. Scholar, Warszawa.

Maciejewska, M. (2012), "Exhausted Bodies and Precious Products: Women's Work in a Special Economic Zone for the Electronics Industry in Poland." Work Organisation, Labour \& Globalisation, Vol 6 No. 2, pp. 94-112.

Maciejewska, M. (2016), 'Union busting is disgusting': labour conflicts at LG corporation in Poland in J. Drahokoupil, R. Andrijasevic, and D. Sacchetto, (eds) Flexible workforces 
and low profit margins: electronics assembly between Europe and China ETUI, Brussels, pp. 187-203.

Meardi, G. (2007), 'More voice after more exit? Unstable industrial relations in Central and Eastern Europe, Industrial Relations Journal, Vol. 38 No. 6, pp. 503-523.

Mrozowicki A. and Maciejewska, M. (2013), 'Conflicts at Work in Poland's

New Capitalism: Worker Resistance in a Flexible Work Regime', in G. Gall, (ed.) New Forms and Expressions of Conflict at Work, Palgrave, Basingstoke, pp. 191-211.

Mrozowicki, A. and Maciejewska, M. (2017), 'Bricolage unionism. Unions' innovative responses to the problems of precarious work in Poland' in M. Bernaciak and M.

Kahancová (eds), Innovative union practices in Central-Eastern Europe. ETUI, Brussels pp. 139-159.

Mrozowicki, A., Pulignano, V., and Van Hootegem, G. (2009), Worker agency and trade union renewal: the case of Poland, Work, Employment and Society, Vol. 24 No. 2, pp. 221240.

Myant, M. and Drahokoupil, J. (2012), 'International integration, varieties of capitalism and resilience to crisis in transition economies', Europe-Asia Studies, Vol. 64 No. 1, pp. 133.

Nölke, A. and Vliegenthart, A. (2009), 'Enlarging the varieties of capitalism: the emergence of dependent market economies in East Central Europe', World Politics, Vol. 61 No. 4 , pp. $670-702$.

Ost, D. (2005), The Defeat of Solidarity: Anger and Politics in Postcommunist Europe, Cornell University Press, Ithaca NY. 
Ost, D. and Weinstein, M. (1999), 'Unionists Against Unionists: Towards Hierarchical Management in Postcommunist Poland', East European Politics and Societies, Vol 13 No. 1, pp. 1-33.

Peck, J. (1996), Work Place: The Social Regulation of Labour Markets. Guildford Press, New York and London.

Pulignano, V. and Doerflinger, N. (2018), 'Expanding social-actor based social explanations in labour market dualisation research: a combined macro-micro and micro-macro approach', Employee Relations, Vol. 40 No. 1, pp. 75-88.

Pulignano, V. and Keune, M. (2015), 'Understanding varieties of flexibility and security in multinationals: product markets, institutional variation and local bargaining', European Journal of Industrial Relations, Vol. 21 No. 1, pp. 5-21.

Rainnie, A. and Hardy, J. (1995), 'Desperately seeking capitalism: Solidarity and Polish industrial relations in the 1990s, Industrial Relations Journal, Vol. 26 No. 4, pp. 267-279. Rainnie, A., McGrath-Champ, S. and Herod A. (2010), 'Making space for geography in the labour process theory' in P. Thompson and C. Smith (eds) Working Life: Renewing Labour Process Analysis, Palgrave, Basingstoke, pp. 297-315.

Rapacki, R., Gardawski, J., Czerniak, A., Horbaczewska, B., Karbowski, A., Maszczyk, P. and Prochniak, M. (2020), 'Emerging varieties of post-communist capitalism in Central and Eastern Europe: where do we stand?', Europe-Asia Studies, DOI:

10.1080/09668136.2019.1704222.

Richards, J. (2008), '"Because I need somewhere to vent": the expression of conflict through workblogs', New Technology, Work and Employment, Vol. 23, No. 1 and 2, pp. 95-109. 
Schoneboom, A. (2011), 'Sleeping Giants? Fired Workbloggers and Labour

Organisation', New Technology, Work and Employment, Vol. 26 No. 1, pp. 17-28.

Taylor, P. and Bain, P. (2003), “'Subterranean worksick blues”: humour as subversion in two call centres', Organization Studies, Vol. 24 No. 9, pp. 1487-509.

Ward, K. (2007), 'Think geographically about work, employment and society', Work, Employment and Society, Vol. 21 No. 2, pp. 265-276.

Webb, M. and Palmer, G. (1998), 'Evading surveillance and making time: an ethnographic view of the Japanese floor in Britain', British Journal of Industrial Relations Vol. 36 No. 4, pp. 611-627. 
Table 1

Summary of interviews

\begin{tabular}{|l|c|c|l|}
\hline $\begin{array}{c}\text { Company } \\
\text { Pseudonym }\end{array}$ & Sector & $\begin{array}{l}\text { Number of } \\
\text { interviews }\end{array}$ & $\begin{array}{l}\text { Number of } \\
\text { employees }\end{array}$ \\
\hline Kessho & $\begin{array}{c}\text { Electronics } \\
\text { (main assembler) }\end{array}$ & 8 & 1,500 \\
\hline Matado & $\begin{array}{c}\text { Electronics } \\
\text { (supplier) }\end{array}$ & 8 & 800 \\
\hline Izumo I & $\begin{array}{c}\text { Automotive } \\
\text { supplier } \\
\text { (engines and } \\
\text { gearboxes) }\end{array}$ & 9 & 1,500 \\
\hline Izumo II & $\begin{array}{c}\text { Automotive } \\
\text { supplier } \\
\text { (engines and } \\
\text { gearboxes) }\end{array}$ & 5 & 500 \\
\hline
\end{tabular}


Table 2

Unemployment (percentage) in Wałbrzych and Torun and the surrounding areas $2000-2018$

\begin{tabular}{|l|l|l|l|l|}
\hline Wałbrzych Special Economic Zone & 2000 & 2006 & 2015 & 2018 \\
\hline Wałbrzych urban district (powiat grodzki) & 18 & n.d & 14 & 7 \\
\hline Wałbrzych country district (powiat ziemski) & 30 & 27 & 26 & 15 \\
\hline Voivodeship (Dolnośląskie) & 16 & 21 & 11 & 9 \\
\hline $\begin{array}{l}\text { Pomeranian (Crystal Park) Special } \\
\text { Economic Zone }\end{array}$ & 2003 & 2006 & 2015 & 2018 \\
\hline Toruń urban district (powiat grodzki) & 15 & 12 & 8 & 5 \\
\hline Toruń country district (powiat ziemski) & 28 & 30 & 19 & 12 \\
\hline Voivodeship (Kujawsko-Pomorskie) & 23 & 23 & 16 & 9 \\
\hline
\end{tabular}

Source: Powiatowy Urząd Pracy (Toruń and Wałbrzych) 


\section{Table 3}

Trade unions in two automotive case study firms in Wałbrzych SEZ

\begin{tabular}{|c|c|c|c|}
\hline Company & Trade Unions & Union density & Members \\
\hline \multirow[t]{3}{*}{ Izumo I } & Solidarność & \multirow[t]{3}{*}{60 per cent } & $500(2017)$ \\
\hline & OPZZ & & 250 (2017) \\
\hline & KADRA & & 150 (2017) \\
\hline \multirow[t]{2}{*}{ Izumo II } & Solidarnośc & \multirow[t]{2}{*}{50 per cent } & 200 (2017) \\
\hline & OPZZ & & 100 (2017) \\
\hline
\end{tabular}

Source: Author based on data drawn from interviews 
Table 4

Trade unions in electronics firms in Pomeranian SEZ

\begin{tabular}{|c|c|c|c|}
\hline Company & Trade Unions & Union density & Members \\
\hline Kessho & Solidarność & 10 per cent & $180(2011)$ \\
& Solidarność & 30 per cent & $170(2011)$ \\
\hline Matado & & & \\
\hline
\end{tabular}

Source: Author based on data drawn from interviews with trade unionists. 